\title{
KAJIAN BIOAKTIVITAS ANTIBAKTERI DAN SENYAWA METABOLIT SEKUNDER SPONS LAUT Haliclona sp., DARI PERAIRAN TANJUNG TIRAM MORAMO UTARA, SULAWESI TENGGARA
}

\section{Study of Antibacteria Bioactivity and Metabolites Secondary Compounds of Marine Sponge Haliclona sp. from Tanjung Tiram Waters, North Moramo, South-East Sulawesi}

\author{
Muhamad Fajrin Ode ${ }^{1}$, Muhammad Ramli ${ }^{2}$, Sahidin $^{3}$ \\ 1,2Jurusan Ilmu Kelautan, Fakultas Perikanan dan Ilmu Kelautan, UHO \\ ${ }^{3}$ Jurusan Farmasi, Fakultas Farmasi, UHO \\ Jln. H.E.A Mokodompit Kampus Bumi Tridharma Anduonohu Kendari 93232, Telp: (0401)3193782
}

\begin{abstract}
Abstrak
Spons merupakan salah satu komponen organisme penyusun terumbu karang yang menghasilkan senyawa metabolit sekunder dan mempunyai potensi yang belum banyak dimanfaatkan. Penelitian ini bertujuan untuk mengidentifikasi senyawa metabolit sekunder dan bioaktivitas antibakteri ekstrak aseton spons Haliclona sp. terhadap tiga bakteri pathogen Salmonella typhi, Staphylococcus aureus dan Escherichia coli. Pengujian dan identifikasi senyawa metabolit sekunder dilakukan dengan menggunakan reagen (pereaksi). Sedangkan aktivitas antibakteri dilakukan dengan metode difusi cakram. Hasil penelitian menunjukkan bahwa ekstrak aseton spons Haliclona sp. teridentifikasi senyawa alkaloid, flavonoid, steroid, terpenoid, tannin (terkondensasi) dan saponin. Sedangkan kemampuan bioaktivitas antibakteri ekstrak aseton spons Haliclona sp. dikategorikan sedang terhadap bakteri S. typhi, dan dikategorikan lemah terhadap bakteri E. coli dan $S$. aureus. Ekstrak aseton dari spons Haliclona sp. menunjukkan potensi aktivitas inhibitor pertumbuhan bakteri patogen (antibakteri) terhadap S. typhi.
\end{abstract}

Kata Kunci: Antibakteri, Senyawa Metabolit Sekunder, Spons.

\begin{abstract}
A Sponge is one component of coral reef organism that produces secondary metabolites compounds and has potential that has not been widely used. This study aims to determine the secondary metabolite compounds and antibacterial bioactivity acetone extract of Haliclona sp. against pathogen bacteria (Salmonella typhi, Staphylococcus aureus and Escherichia coli). Testing and identifying the secondary metabolite compounds was carried out using reagents (solvents). While the antibacterial activity was carried out by disc diffusion method. The results showed that acetone extract sponge of Haliclona sp. was identified alkaloid compound, flavonoids, steroids, terpenoids, tannins, and saponins. Whereas the antibacterial bioactivity acetone extract of Haliclona sp. categorized as being moderate to $S$. Typhi bacteria and categorized as weak in E. coli and $S$. aureus bacteria. Acetone extract sponge of Haliclona sp. showed that potential inhibitory activity of pathogen bacteria (Antibacteria) againstS. typhi.
\end{abstract}

Keywords: Antibacterial, Secondary Metabolite Compounds, Sponge.

\section{Pendahuluan}

Metabolit sekunder merupakan senyawa yang tidak esensial bagi pertumbuhan mahluk hidup. Senyawa metabolit sekunder disintesis atau dihasilkan dalam jumlah berlebih oleh organisme pada keadaan tertentu. Setiap organisme mensintesis senyawa metabolit sekunder berbeda-beda.Bagi organisme tertentu senyawa metabolit sekunder dimanfaatkan sebagai pertahanan diri dari cekaman biotik maupun abiotik. Senyawa metabolit sekunder

dapat besifat racun dan juga bersifat zat yang menguntungkan, tergantung dari senyawa yang terbentuk. Metabolit sekunder yang bermanfaat dapat digunakan sebagai bahan baku obat dan kosmetik dalam bidang farmakologi maupun industri (Muniarsih, 2005; Setyorini \& Yusnawan, 2016).

Sumber senyawa metabolit sekunder di laut sangat berlimpah dan menunjukkan struktur senyawa kimia aktif yang sangat beragam.Hal ini disebabkan karena tingkat 
keanekaragaman sumberdaya laut yang sangat tinggi.Berbagai usaha telah dilakukan manusia untuk menyingkap rahasia yang terkandung dalam biota laut. Usaha yang tak kenal lelah mulai menunjukkan hasil dengan ditemukannya berbagai jenis senyawa bioaktif baru (novel compounds) yang tidak ditemukan pada biota darat (Rasyid, 2008).

Pencarian senyawa aktif metabolit sekunder biota laut yang potensial mengalami perkembangan dari tahun ke tahun. Data menunjukkan bahwa dari tahun 1990 - 2009 pencarian senyawa aktif dari organisme avertebrata laut mengalami peningkatan jumlah senyawa alami yang baru ditemukan Leal et al.,(2012) dan telah tercatat hingga tahun 2006 sintesis bioaktif alami yang berasal dari perairan laut diperkirakan sekitar 6.914 senyawa aktif yang telah diidentifikasi dan diketahui (Glaser and Mayer, 2009).

Spons merupakan salah satu komponen biota penyusun terumbu karang yang penyebarannya cukup luas di perairan laut. Menurut pernyataan Castro \& Huber (2007), bahwa walaupun tidak terlihat memiliki pertahanan, spons sangat jarang dimakan oleh beberapa jenis ikan dan kepiting.Kenyataan inilah yang dijadikan acuan bahwa spons tersebut memiliki semacam mekanisme pertahanan diri dari organisme predator.

Spons Haliclona sp. adalah salah satu jenis spons yang hidup pada perairan laut dan banyak ditemukan pada daerah ekosistem terumbu karang Handojo, (2006). Kandungan metabolit sekunder dari spons diketahui mampu menangkal dan menghambat bakteri patogen pengganggunya. Hal ini yang membuat spons menjadi salah satu biota laut yang menarik untuk diteliti karena berpotensi besar untuk dikembangkan dalam bidang farmakologi yakni sebagai antibakteri (Suparno, 2005; Abubakaret al., 2011).

Beberapa hasil penelitian terdahulu terkait potensi senyawa aktif metabolit sekunder spons yakni seperti yang dilaporkan Trianto \& Ambaryanto, (2005) mengungkapkan bahwa senyawa aktif spons Haliclona sp. dari Perairan Pulau Panjang, Jepara memiliki potensi aktivitas sebagai Antikanker leukimia. Dan juga dari genus yang sama yakni Haliclona cymaeformis yang berasaldari perairan Talango, Madura memiliki aktivitas sebagai antimikroba (Herdhiansyah et al., 2015)

Namun demikian, kemampuan sintesis senyawa metabolit sekunder oleh spons serta bioaktivitasnya sangat berbeda dari satu perairan dengan perairan lainnya.Hal ini disebabkan karena pola karakteristik perairan maupun lingkungan tersebut yang berbeda.Pada Perairan Tanjung Tiram, Kecamatan Moramo Utara memiliki perairan yang cukup baik. Akan tetapi menurut Mardianto et al., (2016) bahwa kondisi arus perairan Tanjung Tiram sangat kuat dikarenakan letaknya yang berhadapan secara langsung dengan Laut Banda.

Saat ini, penelitian tentang kajian metabolit sekunder dan kemampuan bioaktivitas antibakteri dari jenis spons Haliclona sp. masih sedikit dilakukan khususnya di Perairan Sulawesi Tenggara. Sehingga hal tersebutlah yang menjadi acuan dasar mengapa perlu dilakukan penelitian ini.

Berdasarkan uraian rumusan masalah tersebut, maka tujuan dari penelitian ini yaitu untuk mengetahui metabolit sekunder yang terkandung pada ekstrak aseton spons Haliclona sp. serta mengetahui bioaktivitas ekstrak aseton spons Haliclona sp.terhadap bakteri E. coli, S. aureus dan S. typhi.

Sedangkan Manfaat dari penelitian ini yaitu diharapkan hasil penelitian dapat menjadi sumber informasi ilmiah dalam bidang kelautan dan perikanan terkait potensi senyawa bioaktif sumberdaya perairan yakni spons Haliclona sp. sehingga pada akhirnya dapat dikembangkan lebih lanjut sebagai sumberdaya perairan yang potensial. Sedangkan dalam bidang lainnya yakni dalam bidang farmakologi maupun keperluan industri dapat dijadikan sebagai referensi awal sehingga dapat dimanfaatkan kedepannya sebagai bahan baku obat-obatan.

\section{Bahan dan Metode}

Penelitian ini dilaksanakan pada bulan Mei-Juli 2018. Penelitian dilaksanakan pada dua tempat berbeda yaitu: Penelitian lapangan berupa lokasi pengambilan sampel penelitian yang dilakukan di Perairan Desa Tanjung Tiram, Kecamatan Moramo Utara, Sulawesi Tenggara. Analisis laboratorium dilakukan di Laboratorium Teknologi Bahan Alam dan Laboratorium Mikrobiologi Farmasi, Fakultas Farmasi, Universitas Halu Oleo, Kendari. 


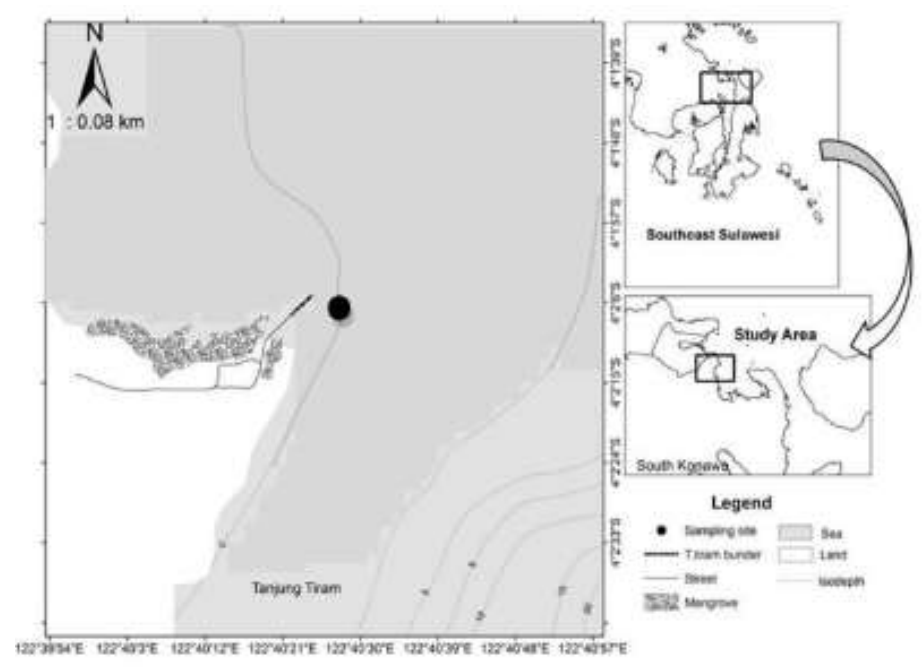

Gambar 1. Lokasi Pengambilan Sampel

Alat yang digunakan pada penelitian ini yaitu rotary vacum evaporator, mikropipet, cawan petri, tabung reaksi, inkubator, pipet tetes, hot plate, erlenmeyer, autoklaf, dan peralatan penunjang lainnya. Sedangkan bahan yang digunakan yaitu Haliclona sp., larutan aseton, reagen (larutan pereaksi), media NA (Natrium agar) dan NB (Natrium Broth), bakteri uji (E. coli, $S$. aureus dan $S$. typhi), Kloramfenikol, Dimetil sulfoksida (DMSO), aquades steril dan bahan penunjang lainnya.

Sampel yang digunakan pada penelitian ini adalah spons laut dari spesies Haliclona sp. (Gambar 2). Pengambilan sampel di perairan berdasarkan keberadaan sampel spons menggunakan metode koleksi bebas (free hand-packing) dengan bantuan peralatan dasar selam.

Metode ekstraksi yang digunakan yaitu dengan metode maserasi. Sebanyak $800 \mathrm{~g}$ berat basah sampel spons ditimbang dan dimaserasi dengan $\pm 1000 \mathrm{~mL}$ larutan aseton selama 3 x 24 jam dalam suhu ruang. Hasil maserasi dipekatkan dengan menggunakan rotary vacum evaporator.

Identifikasi senyawa metabolit sekunder dilakukan dengan menggunakan larutan pereaksi spesifik (Reagen) untuk mengetahui senyawa metabolit skunder yang terkandung dalam ekstrak aseton spons Haliclona sp:

\section{1) Senyawa Alkaloid}

Identifikasi senyawa alkaloid yaitu di ambil sebanyak $1 \mathrm{~mL}$ ekstrak spons ditambah dengan 3 tetes amonia $10 \%$ dan $1,5 \mathrm{~mL}$ kloroform, lalu dikocok. Lapisan kloroform diambil kemudian dilarutkan dalam $1 \mathrm{~mL}$ asam sulfat $2 \mathrm{~N}$, kemudian dikocok.Setelah itu, ekstrak ditambahkan dengan reagen.Terbentuknya endapan putih dengan menggunakan pereaksi Meyer menandakan adanya senyawa alkaloid Harborne, (2006).Terbentuknya endapan coklat positif dengan pereaksi Wagner menanadakan ada alkaloid. Pereaksi Dragendorff, ada endapan coklat/putih ungu kemerahan positif adanya alkaloid. Terbentuknya endapan jingga pada tabung kedua dan endapan putih hingga kekuningan pada tabung ketiga menunjukkan adanya senyawa alkaloid pada sampel (Jones \& Kinghorn, 2006).

\section{2) Senyawa Saponin}

Identifikasi senyawa saponin yaitu sebanyak $1 \mathrm{~mL}$ ekstrak sponge ditambah dengan $20 \mathrm{~mL}$ akuades, kemudian dipanaskan selama 5 menit.Larutan dituang ke dalam tabung reaksi dalam keadaan panas. Larutan diambil sebanyak $10 \mathrm{~mL}$, kemudian dikocok kuat secara vertical selama 10 detik.Adanya saponin ditandai dengan terbentuknya busa yang stabil setinggi 1-10 $\mathrm{cm}$ selama 10 menit dan tidak hilang pada saat ditambahkan dengan satu tetes $\mathrm{HCl} 2 \mathrm{~N}$ (Harborne, 2006).

\section{3) Senyawa Steroid dan Terpenoid}

Identifikasi senyawa steroid dan terpenoid yaitu sebanyak $1 \mathrm{~mL}$ ekstrak spons ditambah dengan $2 \mathrm{~mL}$ kloroform dalam tabung reaksi, kemudian diteteskan ke dalam plat tetes, dan dibiarkan sampai kering. 
Setelah itu, ditambahkan dengan 1 tetes pereaksi Lieberman-Burchard.Terbentuknya warna coklat menandakan adanya senyawa terpenoid dan terbentuknya warna biru atau ungu menandakan adanya senyawa steroid (Harborne, 2006).

\section{4) Senyawa Flavonoid}

Pengujian flavonoid dilakukan dengan cara ekstrak spons diambil $0.05 \mathrm{~g}$ ekstrak spons dan diteteskan pada 2 tabung reaksi. Satu bagian tabung reaksi sebagai kontrol, lalu sisanya dapat diidentifikasi dengan menambahkan 0,1 mg hingga 1-2 butir bubuk logam magnesium dan beberapa tetesasam klorida $(\mathrm{HCl})$ pekat. Terbentuknya warna jingga, ungu, kuning, merah muda sampai merah menandakan adanya senyawa flavonoid (Romansyah, 2011).

\section{5) Senyawa Tanin/fenol}

Pengujian senyawa fenol yaitu dilakukan dengan cara ekstrak spons diambil $1 \mathrm{~mL}$ dan ditempatkan pada 2 tabung reaksi. Satu bagian tabung reaksi sebagai kontrol dan sisanya ditetesi dengan larutan $\mathrm{FeCl}_{3}$. Fenol positif apabila timbul warna biru sampai hitam. Selanjutnya untuk pengujian tanin yaitu dengan cara $2 \mathrm{~mL}$ ekstrak sampel spons dan ditambah $100 \mathrm{~mL}$ air panas, dididihkan selama 15 menit kemudian disaring kedalam masing-masing $5 \mathrm{~mL} \mathrm{FeCl}_{3} 1 \%$ dan larutan gelatin. Hasil positif (teridentifikasi tanin) menunjukkan terbentuknya endapan putih atau merah muda (Hafizah et al., 2016).

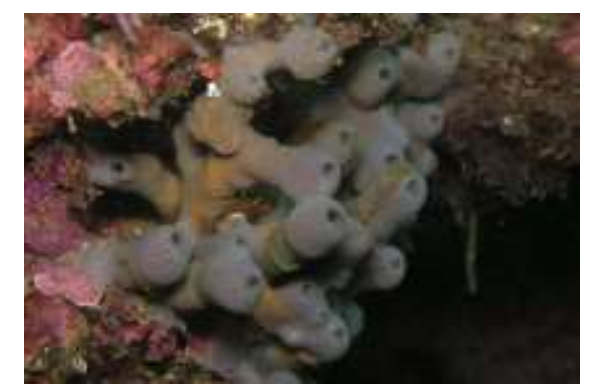

Gambar 2. Morfologi Spons kelas Haliclona (sumber : www.sealifebase.oc)

\section{6) Uji Aktivitas Antibakteri}

Metode dalam pengujian aktivitas antibakteri dilakukan dengan metode difusi agar dengan menggunakan kertas cakram yang berdiameter $6 \mathrm{~mm}$ dengan daya serap $50 \mu \mathrm{L}$ (Wewengkang et al., 2014).

Konsentrasi ekstrak aseton spons Haliclona sp. yang digunakan pada pengujian aktivitas antibakteri yaitu kosentrasi $50 \mathrm{ppm}$, 100 ppm dan 200 ppm serta pemberian kloramfenikol sebagai kontrol positif dan DMSO sebagai kontrol negatifyang di uji terhadap bakteri patogen yaitu $E$. coli, $S$. aureus, dan S. typhi.

Isolat murni bakteri uji diperoleh dari Labolatorium Farmasi, Universitas Halu Oleo, Kendari. Media pertumbuhan bakteri yang digunakan adalah media NA (Natrium Agar) dan media NB (Natrium Broth).Bakteri uji yang telah didifusikan dengan kertas cakram ekstrak spons diinkubasi di dalam inkubator dengan suhu $27-28^{\circ} \mathrm{C}$ selama 24 jam. Pengamatan diameter daya hambat aktivitas antibakteri ekstrak aseton spons Haliclona sp. diamati selama 1x24 jam untuk mengetahui respon bakteri uji terhadap ekstrak spons.

\section{Hasil dan Pembahasan}

Rata-rata berat dan persentase rendeman ekstrak aseton spons Haliclona sp. yang telah dipekatkan dengan rotary facum eveporator yaitu diperoleh berat ekstrak sebesar 14,31 g dengan presentase sebesar $1,78 \%$. (Tabel 1.). Pada dasarnya ada beberapa hal yang diduga sangat mempengaruhi berat dan rendeman ekstrak simplisia pada proses ekstraksi. Pertama yaitu metode yang digunakan dalam proses ekstraksi. Hal ini diduga bahwa setiap metode ekstraksi yang digunakan memiliki kemampuan atau keunggulan tersendiri dalam manarik komponen-komponen senyawa yang ada di dalam sampel. Pada dasarnya ada beberapa hal yang diduga sangat mempengaruhi berat dan rendeman ekstrak pada simplisia saat proses ekstraksi. Pertama yaitu metode yang digunakan dalam proses ekstraksi. Hal ini diduga bahwa setiap metode ekstraksi yang digunakan memiliki kemampuan atau keunggulan tersendiri dalam manarik komponen-komponen senyawa yang ada di dalam sampel.

Pada umumnya metode yang digunakan dalam proses pengekstrakan senyawa bahan alam yaitu dengan metode maserasi (perendeman dengan pelarut) karena metode tersebut efisien dan efektif dalam menarik komponen senyawa dari sampel. Menurut Marraskuranto, (2010) bahwa proses ektraksi (metode maserasi) diharapkan semua komponen senyawa kimia yang terkandung di dalam jaringan spons terekstrak atau tertarik dan terlarut dalam cairan pelarut. 
Table 1. Rata-rata Berat dan Rendeman Ekstrak Aseton Spons Haliclona sp. dengan Metode Maserasi

\begin{tabular}{lcccc}
\hline Jenis spons & $\begin{array}{c}\text { Berat awal } \\
\text { sampel } \\
(\mathbf{g})\end{array}$ & Pelarut $(\mathbf{m L})$ & Berat Ekstrak $(\mathbf{g})$ & $\begin{array}{c}\text { Rendeman } \\
\text { Ekstrak } \\
(\boldsymbol{\%})\end{array}$ \\
\hline Haliclona sp. & 800 & 3000 & 14,31 & 1,78 \\
\hline
\end{tabular}

Tabel 2. Senyawa Metabolit Sekunder yang Diidentifikasi pada Ekstrak Aseton Spons Haliclona sp.

\begin{tabular}{clc}
\hline $\begin{array}{c}\text { Senyawa } \\
\text { Metabolit } \\
\text { Sekunder }\end{array}$ & $\begin{array}{c}\text { Hasil Pengujian dan Identifikasi } \\
\text { Metabolit Sekunder Ekstrak Aseton } \\
\text { Spons Haliclona } \text { sp. }\end{array}$ & Keterangan \\
\hline Alkaloid & $\begin{array}{l}\text { Endapan putih (Meyer), endapan coklat } \\
\text { pekat (Wagner), endapan putih keunguan } \\
\text { (Dragendroff) }\end{array}$ & Positif Teridentifikasi [+] \\
Flavonoid & Warna Merah & Positif Teridentifikasi [+] \\
$\begin{array}{c}\text { Steroid dan } \\
\text { Terpenoid } \\
\text { Tanin }\end{array}$ & Warna biru pekat ke coklat pekat & Positif Teridentifikasi [+] \\
Saponin & Busa stabil & $\begin{array}{c}\text { Positif Teridentifikasi [+] } \\
\text { (Tanin Terkondensasi) }\end{array}$ \\
\hline
\end{tabular}

Kedua, waktu dan ukuran sampel yang digunakan saat proses maserasi juga memiliki pengaruh dalam menghasilkan berat dan rendeman ekstrak pada simplisia. Hal ini diduga bahwa waktu dan ukuran sampel yang digunakan saat proses maserasi berkaitan dengan adanya proses pemecahan dinding sel dari simplisia terlebih dahulu sebelum terjadi perlautan senyawa oleh pelarut.

Ketiga yaitu tingkat kepolaran dari suatu pelarut juga sangat berpengaruh pada berat dan presentase rendeman ekstrak yang diperoleh. Hal ini disebabkan karena tingkat kepolaran suatu senyawa hanya akan larut pada pelarut yang memiliki tingkat kesamaan polaritas dengan senyawa tersebut. Hal tersebut sependapat dengan pernyataan Sayuti, (2017) bahwa perbedaan jenis pelarut yang digunakan memberikan pengaruh yang signifikan terhadap rendeman hasil eksraksi karena senyawa yang bersifat non polar akan larut dalam pelarut non polar, sedangkan senyawa yang bersifat semi polar akan larut dalam pelarut semi polar serta senyawa yang bersifat polar akan larut dalam pelarut polar.

\section{Senyawa Metabolit Sekunder Spons}

Hasil pengujian dan identifikasi senyawa metabolit sekunder ekstrak aseton spons Haliclona sp. yaitu dinyatakan positif mengandung beberapa senyawa metabolit sekunder diantaranya yaitu senyawa alkaloid, flavonoid, steroid, terpenoid, tanin dan saponin (Tabel 2.). Hasil penelitian yang diperoleh sesuai dengan beberapa hasil penelitian sebelumnya yaitu menurut Arai et al., (2011) bahwa spons Haliclona sp. memiliki senyawa makrosiklik alkaloid sebagai anti-dormant, serta menurut hasil penelitian Wewengkang et al., (2014) bahwa spons Haliclona sp. juga mengandung beberapa senyawa metabolit seperti senyawa alkaloida, senyawa flavonoid, antrakuinon dan beberapa senyawa lainnya.

Senyawa alkaloid merupakan salah satu senyawa metabolit sekunder yang diidentifikasi. Hasil pengujian dan identifikasi menunjukkan bahwa ekstrak aseton spons Haliclona sp. positif mengandung senyawa alkaloid setelah diuji dengan menggunakan reagen (larutan pereaksi). Hal tersebut dibuktikan dengan terbentuknya endapan putih setelah direaksikan dengan pereaksi Wagner, endapan coklat dengan pereaksi Meyer, serta endapan putih keunguan dengan pereaksi Dragendroff. Menurut Sidiq, (2018) bahwa endapan putih (Meyer), endapan coklat (Wagner), dan endapan endapan putih keunguan (dragendroff) yang terbentuk 
merupakan senyawa kompleks kaliumalkaloid. Senyawa alkaloid memiliki kemampuan mekanisme dalam penghambatan bakteri. Menurut Wulandari et al., (2009); Smith et al., (2011) bahwa senyawa alkaloid diduga memiliki mekanisme penghambatan bakteri dengan cara merusak dari komponen penyusun peptidoglikan pada sel mikroba sehingga lapisan dinding sel tidak terbentuk secara utuh dan pada akhirnya menyebabkan kematian sel bakteri tersebut.

Selain senyawa golongan alkaloid yang positif teridentifikasi, ekstrak spons Haliclona sp. juga teridentifikasi senyawa golongan flavonoid. Hasil pengujian dan identifikasi menunjukan bahwa adanya reaksi antara ekstrak dan pereaksi sehingga membentuk warna merah.Hal ini diduga bahwa warna merah yang terbentuk tersebut adalah hasil reduksi senyawa flavonoid yang ada pada ekstrak spons terhadap pereaksi yang digunakan. Hal ini sesuai dengan pernyataan Rusman, (2015) bahwa warna merah yang terbentuk atau yang dihasilkan merupakan hasil dari reduksi senyawa flavonoid (antosianin, flavo, dan flavonol) oleh logam magnesium dalam larutan asam klorida.Senyawa flavonoid memiliki kemampuan aktivitas antibakteri dengan memiliki mekanisme kerja dalam menghambat dan mengganggu fungsi dan sintem kerja pada dinding sel bakteri. Menurut Jaya, (2010) bahwa kemampuan senyawa flavonoid terhadap bakteri yaitu dengan mengganggu sintesis membran sel bakteri melalui penghambatan yang mengakibatkan penggabungan rantai glikan sehingga membran sel dan peptidoglikan melemah dan kemudian menyebabkan kerusakan yang dapat berakibat lisis pada dinding sel.

Hasil pengujian ekstrak aseton spons Haliclona sp. menunjukkan bahwa positif teridentifikasi senyawa steroid dan senyawa terpenoid. Dari hasil pengujian terlihat bahwa adanya reaksi antara ekstrak spons dengan pereaksi sehingga terbentuk warna biru hingga coklat pekat. Menurut Ayoola et al., (2008) bahwa warna coklat yang terbentuk merupakan reaksi senyawa terpenoid pada ekstrak spons dengan pereaksi Liberaman burchard. Pada dasarnya Senyawa golongan steroid dan terpenoid memiliki kemampuan dalam merusak membran sel bakteri.Hal ini sesuai dengan pernyataan Mayanti (2010), bahwa Pada umummnya sifat senyawa steroid yang cenderung bersifat lipofilik yakni dengan merusak membran sel pada bakteri. Sedangkan pada senyawa terpenoid menurut Leon et al., (2010) bahwa senyawa terpenoid memiliki mekanisme kerja dengan target utama yaitu dengan merusak membran sitoplasma sehingga pertumbuhan bakteri terhambat atau mati.

Hasil pengujian juga menunjukkan bahwa ekstrak aseton spons Haliclona sp. positif mengandung tanin. Hal ini diduga bahwa terbentuknya warna merah muda setelah direaksikan atau pemberian larutan pereaksi $\mathrm{FeCl}_{3}$ merupakan tanin terkondensasi. Hal ini sesuai dengan pernyataan Sariet al., (2015) bahwa adanya perubahan warna merah muda yang terbentuk setelah direaksikan dengan $\mathrm{FeCl}_{3}$ maka termaksud tanin terkondensasi sedangkan jika terbentuk warna hitam maka positif mengandung tanin terhidrolisis. Senyawa tanin memiliki kemampuan aktivitas sebagai antibakteri dengan memiliki fungsi target merusak enzim bakteri. Menurut Akiyama et al., (2001); Nuria et al., (2009) bahwa senyawa tanin memiliki kemampuan antiakteri yaitu dengan menghambat enzim reverse transkiptase dan DNA topoisomerase sehingga sel bakteri tidak dapat terbentuk oleh kapasitas pengikat besi yang kuat oleh senyawa tanin.

Hasil identifikasi senyawa saponin pada ekstrak aseton spons Haliclona sp. menunjukkan bahwa senyawa saponin positif teridentifikasi dengan terbentuknya busa yang stabil. Menurut Fadlian et al., (2016) bahwa busa yang timbul disebabkan karena senyawa saponin mengandung senyawa yang sebagian larut dalam air (hidrofilik) dan senyawa yang larut dalam pelarut nonpolar (hidrofobik) sebagai surfaktan yang dapat menurunkan tegangan permukaan. Senyawa saponin memiliki kemampuan sebagai antibakteri dengan merusak permukaan dinding sel bakteri. Mekanisme kerja senyawa saponin sebagai antibakteri menurut Harbone, (2006); Madduluri et al., (2013) yaitu dengan menyebabkan kebocoran protein dan enzim dari dalam sel mikroba.Selain itu, saponin menurunkan tegangan permukaan dinding sel bakteri dan merusak permeabilitas bakteri. 
Tabel 3. Rata-Rata Diameter Daya Hambat (DDH), Standar Deviasi dan Interpretasi Ekstrak Aseton Spons Haliclona sp. Terhadap Tiga Bakteri Patogen.

\begin{tabular}{|c|c|c|}
\hline Bakteri Uji & $\begin{array}{c}\text { Konsentrasi Ekstrak dan } \\
\text { Kontrol }\end{array}$ & $\begin{array}{c}\text { Rata-Rata Diameter Daya Hambat dan } \\
\text { Interpretasi Ekstrak Aseton Spons Haliclona } \\
\text { sp. }(\mathrm{mm})\end{array}$ \\
\hline \multirow{5}{*}{ E. coli } & $200 \mathrm{ppm}$ & $5,83 \pm 0,76[\mathrm{~L}]^{*}$ \\
\hline & $100 \mathrm{ppm}$ & $1,67 \pm 1,53[\mathrm{~L}]^{*}$ \\
\hline & 50 ppm & $0,67 \pm 1,15[\mathrm{~L}]^{*}$ \\
\hline & Kloramfenikol (Kontrol +) & $28,5 \pm 0,87[\mathrm{~K}]^{* *}$ \\
\hline & DMSO (Kontrol -) & $0 \pm 0[\mathrm{TA}]$ \\
\hline \multirow{5}{*}{ S. aureus } & $200 \mathrm{ppm}$ & $9,17 \pm 0,28[\mathrm{~L}]^{*}$ \\
\hline & $100 \mathrm{ppm}$ & $6,5 \pm 2,5[\mathrm{~L}]^{*}$ \\
\hline & 50 ppm & $4,33 \pm 0,28[\mathrm{~L}]^{*}$ \\
\hline & Kloramfenikol (Kontrol +) & $22,33 \pm 0,58[\mathrm{~K}]^{* *}$ \\
\hline & DMSO Kontrol - & $0 \pm 0[\mathrm{TA}]$ \\
\hline \multirow{5}{*}{ S.typhi } & $200 \mathrm{ppm}$ & $12,5 \pm 0,87[\mathrm{~S}]^{*}$ \\
\hline & $100 \mathrm{ppm}$ & $85 \pm 0,5[\mathrm{~L}]^{*}$ \\
\hline & 50 ppm & $4,5 \pm 3,90[\mathrm{~L}]^{*}$ \\
\hline & Kloramfenikol (Kontrol +) & $25,83 \pm 2,47[\mathrm{~K}]^{* *}$ \\
\hline & DMSO (Kontrol -) & $0 \pm 0[\mathrm{TA}]$ \\
\hline Keterangan: & $\begin{array}{l}{[\mathrm{K}]=\text { Kuat, }[\mathrm{S}]=\text { Sedang, }[\mathrm{L}]} \\
{[*]=\text { Monks } \text { et al., }(2002)} \\
{[* *]=\text { Clinical and Labolato }}\end{array}$ & $\begin{array}{l}\text { emah, [TA]= tidak ada aktivitas } \\
\text { Standar Institute (CLSI), (2014) }\end{array}$ \\
\hline
\end{tabular}

\section{Bioaktivitas Antibakteri Ekstrak Aseton Spons}

Kemampuan daya hambat antibakteri ekstrak aseton Haliclona sp. terhadap ketiga bakteri uji S. typhi, S. aureus dan E. coli, menunjukkan bahwa semakin besar konsentrasi yang diberikan maka semakin besar pula daerah hambatan yang terbentuk (Tabel 3). Hal ini diduga karena adanya penambahan senyawa aktif yang semakin besar dengan adanya penambahan konsentrasi yang tinggi pula. Hal ini sebanding dengan penelitian Hafizah et al., (2016) bahwa senyawa aktif yang terdapat pada ekstrak disetiap penambahan konsentrasi akan semakin besar sehingga daya kerja dan menghambat pertumbuhan bakteri makin efektif.

Ketentuan antibakteri secara umum ditentukan berdasarkan daerah hambatan yang terbentuk sekitar kertas cakram yang didifusikan pada media Natrium Agar (NA). Menurut Monkset al., (2002) bahwa daerah hambatan yang terbentuk dengan ukuran diameter $>16 \mathrm{~mm}$ dikategorikan sangat kuat, daerah hambatan 11-16 $\mathrm{mm}$ berarti sedang dan daerah hambatan $<11 \mathrm{~mm}$ berarti lemah.

Hasil interpretasi rata-rata kemampuan daya hambat menujukkan bahwa ekstrak aseton Haliclona sp. dengan pemberian tiga konsentrasi ekstrak yakni 200 ppm, 100 ppm dan $50 \mathrm{ppm}$, memiliki tingkat kemampuan aktivitas yang berbeda-beda terhadap tiga bakteri uji.Hal ini disebabkan karena setiap konsentrasi ekstrak memiliki tingkat konsentrasi zat aktif yang berbeda. Pada bakteri E. coli kemampuan daya hambat ekstrak aseton spons Haliclona sp. dikategorikan lemah.Hal ini diduga karena bakteri E. coli merupakan bakteri gram negatif yang memiliki lapisan dinding sel yang cukup padat dan kompleks. Hal ini dukung oleh pernyataan Baraet al.,(2015); Jawetz, et al.,(2007) bahwa bakteri gram negatif memiliki tiga lapisan dinding sel yang cukup padat dan kompak yakni lapisan luar lipoprotein, lapisan tengah lipopolisakarida dan lapisan dalam peptidoglikan serta membran luar berupa bilayer sehingga proses internalisasi senyawa yang masuk terhambat.

Pada bakteri uji $S$. aureus hasil penelitian menunjukkan bahwa interpretasi rata-rata daya hambat ekstrak aseton spons Haliclona sp. dikategorikan lemah pada semua konsentrasi (Tabel 3). Nilai rata-rata daya hambat ekstrak aseton spons Haliclona sp. pada konsentrasi 200 ppm cukup luas dan mendekati kategori sedang dibandingkan pada bakteri E. coli. Sehingga bisa disimpulkan bahwa ekstrak spons tersebut mampu 
menghambat pertumbuhan bakteri S. aureus. Hal ini diduga bahwa bakteri $S$. aureus merupakan bakteri gram positif yang memiliki lapisan peptidoglikan yang lebih mudah dan rentan ditembus senyawa aktif sehingga sangat mudah mempengaruhinya. Menurut Rumampuk et al., (2017) bahwa bakteri gram negatif mempunyai dinding sel dengan struktur lipopolisakarida yang kompleks yang dapat menghalangi penetrasi ekstrak yang masuk ke dalam sel mikroba sedangkan bakteri gram positif membran luarnya dibentuk oleh lapisan peptidoglikan yang mudah ditembus oleh senyawa aktif dalam bahan uji.

Sedangkan pada bakteri uji $S$. typhi menunjukkan bahwainterpretasi Rata-rata daya hambat ekstrak aseton spons Haliclona sp.dikategorikan sedang pada konsentrasi 200 ppm (Tabel 3). Hal ini diduga bahwa senyawa aktif yang terkandung dalam ekstrak aseton spons Haliclona sp.mampu merusak membran dan dinding sel pada mikroba sehingga menyebabkan metabolit penting didalam sel akan keluar dan akibatnya terjadi kematian sel. Hal ini diperkuat dengan pernyataan Khunaifi, (2010) bahwa penghambatan sintesis dinding bakteri akan menyebabkan dinding bakteri diperlemah dan menjadi lisis sehingga tidak berfungsi lagi dinding sel bakteri dalam mempertahankan bentuk dan melindungi diri.

Jika dibandingkan antara kemampuan diameter daya hambat ekstrak aseton spons Haliclona sp. dengan diameter daya hambat kontrol positif (Kloramfenikol) (Tabel 3) maka dapat dilihat bahwa diameter daya hambat ekstrakaseton spons Haliclona sp. yang terbentuk terhadap tiga bakteri uji masih dibawah kontrol positif (Kloramfenikol).

\section{Kesimpulan}

Berdasarkan hasil dan pembahasan yang telah diuraikan sebelumnya maka dapat disimpulkan bahwa:

1. Senyawa metabolit sekunder yang teridentifikasi pada ekstrak aseton spons Haliclona sp. yaitu senyawa alkaloid, flavonoid, saponin, steroid, terpenoid, dan tanin/polifenol.

2. Kemampuan bioaktivitas ekstrak aseton spons Haliclona sp. yakni dikategorikan sedang terhadap bakteri $S$. typhi dan dikategorikan lemah pada bakteri E. coli dan S. aureus.

\section{Daftar Pustaka}

Abubakar, H., Wahyudi, A. T., Yuhana, M., 2011.Skrining Bakteri yang Berasosiasi dengan Spons Jaspis sp. Sebagai Penghasil Senyawa Mikroba. Jurnal Ilmu Kelautan. Vol. 16 [1] :3540.

Akiyama, H., K. Fujii., O. Yamasaki., T. Oono., dan K. Iwatsuki. 2001. Antibacterial Action of Several Tannin against Staphylococcus aureus. Journal of Antimicrobial Chemotherapy.Vol. 48:487 - 491.

Arai, M. Liu, L., Fujimoto, T., Setiawan, A. Kobayashi, M., 2011. DeadA Protein Relates to Action-Mechanism of Halicyclamine A, a Marine Spongean Macrocyclic Alkaloid, as an AntiDormant Mycobacterial Substance. Mirine Drug. 3148-3149.

Ayoola, G. A., Coker, H. A. B., Adesegun, S. A., Bello, A. A. A., Obaweya, K., Ezennia, E. C. Atangbayila, T. O., 2008. Phytochemical Screening and Antioxidant Activities of Some Selected Medicinal Plants Used for Malaria Therapy in Southwestern Nigeria.Tropical Journal of Pharmacetical Research. Vol. 7 [3]: 1019-1024.

Bara, R. A., Kandou, G. D., Ola, A. R. B., Posangi, J., 2015. Analisis Senyawa Antibiotik dari Jamur Simbion yang Terdapat dalam Ascidian (Didemnum molle) di Sekitar Perairan Bunaken Sulawesi Utara. Jurnal LPPM Bidang Sains aan Teknologi.Vol. 2 [2].

Castro, P., Huber, M. E., 2007. Marine Biology. New York: McGraw-Hill. Hlm. 120-151, 298, 316, 396.

Clinical and Laboratori Standards Institute USA [CLSI]. 2014. M100-S24 Performance Standards from Antimicrobial Susceptibility: TwentyFourth Information Suplement.

Fadlila, W. N., Yuliawati, K. M., Syafnir, L., 2015.Identifikasi Senyawa Aktif Antibakteri dengan Metode Bioautografi KLT Terhadap Ekstrak Etanol Tangkai Daun talas (Colocasia esculenta (L.)Schott). Prosiding Penelitian SPeSIA Unisba

Glaser, K. B., Mayer, A. M. S., 2009. A Reinassance in Marine Pharmacology: from Preclinical Curiosity to Clinical 
Reality Biochemical Pharmacology. Vol. 78: 440-448.

Hafizah, I., Muliati, F. F., Sulastrianah. 2016. Aktivitas Antibakteri Ekstrak Etanol Polifera (Spongia officinalis) Terhadap Staphylococcus aureus [ATCC 25923]. Vol. 4: 1-7

Handojo, K. K., 2006. Distribusi aan Preferensi Habitat Spons Kelas Demospongiae di Kepulauan Seribu Provinsi DKI Jakarta.Thesis. Institute Pertanian Bogor. Bogor

Harbone, J.B., 2006. Metode Fitokimia: Penuntun Cara Moderen Menganalisis Tumbuhan Edisi IV. Kakasih P., and I, Soediro (Penerjemah).ITB. Bandung. 354 Halaman.

Herdhiansyah, R., Zetra Y., Nugraheni Z. V., 2015. Senyawa Lipid Spons Haliclona cymaeformis Sebagai Biomarka dan Aktivitasnya Terhadap Mikroba.Jurnal Sains dan Seni.Vol. 4 [2].

Jaya, A. M. 2010. Isolasi dan Uji Efektivitas Antibakteri Senyawa Saponin dari Akar Putri Malu (Mimosa pudica).Skripsi. Jurusan Kimia. Fakultas Sains dan Teknologi UIN Maulana Malik Ibrahim. Malang.

Jawetz, E., Melnick, J. L., Adelberg, E. A., 2007. Mikrobiologi Kedokteran. Jakarta: Penerbit Buku Kedokteran ECG.

Jones, W. P., and Kinghorn, A. D., 2006.Extraction of Plant Secondary Metabolites. In: Sarker, S. D., Latif, Z. and Gray, A. I., Eds. Natural Products Isolation. 2nd Ed. New Jersey: Humana Press. Pp. 341-342.

Khunaifi, M., 2010. Uji Aktivitas Antibakteri Ekstrak Daun Binahong (Amdredera cordifolia (T.)Steenis) Terhadap Bakteri S. aureus dan Pseudomonas aeruginosa.Universitas Islam Negeri Malang.

Leal, M.C., Puga, J., Serodio, J., Gomes, N.C.M., Calado, R., 2012. Trend in theDiscoveri of New Marine Natural Products from Invertebrates Over the Last Two Decades-Where and What Are We Bioprospecting? Plos ONE 7 [1]:e30580.Doi:10.1371/journal.pone.0 030580.

Leon, L. D., Lopez, M. R., Mouji, L., 2010. Antibakterial Properties of Zeylasterone A Triterpenoid Isolate from Maytenus blepharacles Againts Staphylococcus aureus. Microbial Research. Vol. 12: 12-10.

Mardianto, Nur, A. I., Ramli, M., 2016.Studi Ekologi Bambu Laut (Isis Hippuris) di Perairan Tanjung Tiram, Kecamatan Moramo Utara, Kabupaten Konawe Selatan. Jurnal Manajemen Sumber Daya Perairan. Vol. 1 [3]: 323-332.

Marraskuranto, E., 2010. Kajian Bioprospeksi Spons Laut Asal Taman Nasional Kepulauan Wakatobi dan Implikasi

Pengelolaannya.Thesis.Institut

Pertanian Bogor. Bogor.

Mayanti, T., Euis, j., Yurita, P. A., 2010.Isolasi dan karakterisasi Senyawa Antibakteri dari Fraksi Etil Asetat Kulit Batang (Lansium Domesticum corr. CV kokossam).Jurusan Kimia. Universitas padjajaran. Bandung.

Monks, L. R., Lenner, C., Henriques, A. T., Farias, M., Schapoval,, E. E. S., Suyenaga, E. S., Rocha, B. Schwartsmann, G., Mothes, B. 2002. Anticancer, Antichtemotactic and Antimicrobial Activities of Marine Sponges Collected of The Coast of Santa Catarina, Sothern Brazil. Jaournal of Experimental Marine Biology and Ecology. Vol. 281: 1-12

Murniasih, T., 2005.Substansi Kimia Untuk Pertahanan DiriHewan Laut Tak Bertulang Belakang. Oseana. Vol. 30 [2]: 19-27.

Nuria, M. C., Faizatun, A., Sumantri, 2009. Uji Aktivitas Antibakteri Ekstrak Etanol Daun Jarak Pagar (Jatropha curcas L.) Terhadap Bakteri Staphylococcus aureus[ATCC 25922], Echerichia coli[ATCC 25922], dan Salmonella typhi[ATCC 1408].Jurnal Ilmu-ilmu Pertanian.Vol. 5: 26 - 37

Rasyid, A., 2012.Identification of Secondary Metabolites Compounds, Antibacterial and Antioxidant Activities on The Methanol Extract of Sea Cucumber Stichopus hermanii. Jurnal Ilmu dan Teknologi Kelautan Tropis, Vol. 4 [2]: 360-368.

Romansyah, Y., 2011. Kandungan Senyawa Bioaktif Antioksidan Karang Lunak Sarcophyton sp. Alami dan Transplantasi di Perairan Pulau Pramuka, Kepulauan 
Seribu.Skripsi.Institut Pertanian Bogor.

Rumampuk, Y. J. B., Wowor, P. M., Mambo, C. D., 2017. Uji Daya Hambat Ekstrak Spons Laut (Callyspongia aerizusa) Terhadap Pertumbuhan Bakteri Salmonella typhi dan Streptococcus pyogenes. Jurnal E-Biomedik (eBM). Vol. 5 [2].

Rusman. 2015. Identifikasi Senyawa Metabolit Sekunder Ekstrak Metanol Kulit Buah Aren (Arenga pinnata M.). Skripsi.Universitas Halu Oleo.

Sari, F.P., dan S. M. Sari.2011. Ekstraksi Zat Aktif Antimikroba dari Tanaman Yodium (Jatropha multifida Linn) sebagai Bahan Baku Alternatif Antibiotik Alami. Fakultas Teknik Universitas Diponegoro. Semarang.

Sayuti, M., 2017. Pengaruh Perbedaan Metode Ekstraksi, Bagian dan Jenis Pelarut Terhadap Rendeman dan Aktivitas Antioksidan Bambu Laut (Isis hippuris). Technology Science and Engineering Journal.Vol. 1 [3].

Sealifebase. 2018. Morfologi spons kelas haliclona. Diakses pada www.sealifebase.ca/phot.

Setyorini, S. D., Yusnawan, E., 2016. The Increase of Secondary Metabolite in Legumes as a Response of Biotic Stress. Iptek Tanaman Pangan. Vol. 11 [2].

Sidik, N. 2018. Identifikasi Senyawa Metabolit Sekunder dan Uji Antioksidan Ekstrak Metanol Daun Kapas (Gossypium sp.). Skripsi. Universitas Halu Oleo.

Smith, T. E., 2017. Biogenetic Relationships of Bioactive Sponge Merotriterpenoids.Marine Drugs. Vol. 15 [9]: 285

Suparno. 2005. Kajian Bioaktif Spons Laut (Porifera: Demospongiae) Suatu Peluang Alternatif Pemanfaatan Ekosistem Karang Indonesia dalam Bidang Farmasi. Institut Pertanian Bogor. Bogor.

Trianto, A., Ambaryanto, 2005. Isolasi Senyawa Antikanker Leukimia dari Spons Agelas nakamurai dan Haliclona sp. Fakultas Perikanan dan Ilmu Kelautan.UPT-PUSTAKUNDIP.Universitas Diponegoro
Wewengkang, D. S., Sumilat, D. A., Rotinsulu, H., 2014. Karakterisasi dan Bioaktif Antibakteri Senyawa Spons Haliclona sp. dari Teluk Manado. Jurnal LPPM Bidang Sains dan Teknologi.Vol. 1 [1].

Wulandari, L., 2011. Kromatografi Lapis Tipis.Taman Kampus Presindo. Jember. ISBN:978-979-17068-10. 